\title{
Sektor Ekonomi Kreatif Kuliner Solusi Bagi Perlambatan Pertumbuhan Ekonomi Daerah Kabupaten Fakfak
}

\author{
Ardha Puspitasari ${ }^{1}$, Els Tieneke Rieke Katmo, Agus I. Sumule, Diana N. Irbanyanti ${ }^{1}$, Indra Irianti ${ }^{2}$ \\ ${ }^{1}$ Program Studi Agribisnis Jurusan Sosial Ekonomi Pertanian Fakultas Pertanian \\ ${ }^{2}$ Politeknik Pembangunan Pertanian Manokwari
}

Received: Februari 2020; Accepted: Maret 2020; Published: Maret 2020

\begin{abstract}
Abstrak
Ekonomi kreatif adalah salah satu strategi pembangunan berkelanjutan dalam mengatasi perlambatan pertumbuhan ekonomi yang terjadi di Indonesia, demikian pula di Kabupaten Fakfak, daerah yang memiliki potensi sumberdaya alam yang banyak. Perubahan struktur ekonomi sebagai sektor utama ke sektor industri dan informasi sebagai sumber pertumbuhan ekonomi yang berkelanjutan. Ekonomi kreatif menjadi solusi bagi peningkatan ekonomi wilayah Kabupaten Fakfak yang mengalami perlambatan disatu sisi dan pada sisi yang lain peningkatan jumlah pengaangguran. Hasil dari Analisis Hirarki Proses (AHP) menunjukkan bahwa kuliner adalah sektor ekonomi potensial selain kriya dan pariwisata. Hal ini didukung oleh tingginya skor dalam pembobotan sektor kuliner terutama pada elemen-elemen sumberdaya manusia, sumberdaya alam, pembiayaan, akses pasar, teknologi dan infrastruktur, dan kelembagaan. Hasil AHP mengindikasikan bahwa pemerintah daerah melalui kebijakan ekonomi cukup berperan penting di dalam mendukung sektor kuliner selalu keterlibatan BP Tangguh, perbankan dan lembaga pendidikan tinggi. Oleh sebab itu peningkatan produksi dan deversifikasi produk kuliner berbahan sumberdaya lokal masih perlu dilakukan.
\end{abstract}

Kata kunci: Ekonomi Keberlanjutan, Analisis Hirarki Proses, Ekonomi Kreatif, dan Kuliner

\section{Abstract}

Creative economic is a sustainable development strategy in addressing slow economic growth that occurred in Indonesia as well as in Fakfak, a natural resources richest region. Economic structure alteration from agriculture as primary sector to industry and information sectors indicated the need of innovation and creativity as a new source of sustainable economic growth. Creative economic can be a solution to impove regional economic in Fakfak which have slow economic growth, and high number of unemployement. Result of Hirarchy Process Analysis (HPA) shows that culinary is a potential creative economic sector apart from craft and tourism. This is caused by highest scores that achieved from several supported elements in culinary sector such as human resources, natural resources, cost, market access, technology and infrastructure and institutions. The HPA result also indicated that local government through its economic policies has played important role in supporting kuliner sector as well as economic development program of BP Tangguh, bank and universities or academics. Therefore, increase production and product diversification of local resources based culinary is still needed.

Keywords: Sustainable Economic, Hirarchy Process Analysis, Creative Economic, Culinary

How to Cite: Puspitasari, dkk.. (2020). Sektor Ekonomi Kreatif Kuliner Solusi Bagi Perlambatan Pertumbuhan Ekonomi Daerah Kabupaten Fakfak. JFRES: Journal of Fiscal and Regional Economy Studies, 3 (1), $66-75$

\footnotetext{
Corresponding author

E-mail: a.puspitasari@unipa.ac.id
} 


\section{PENDAHULUAN}

Salah satu pendorong pertumbuhan ekonomi Indonesia yang cenderung mengalami perlambatan adalah ekonomi kreatif. Perubahan struktur ekonomi Indonesia dari sektor pertanian sebagai sektor dominan ke sektor industri dan informasi masih berlangsung hingga saat ini (Sensus Ekonomi, 2016). Perubahan ini mengindikasikan bahwa Indonesia membutuhkan inovasi dan kreativitas sebagai sumber pertumbuhan ekonomi yang berkelanjutan. Demikian pula pertumbuhan ekonomi di Kabupaten Fakfak. Data BPS Kabupaten Fakfak tahun 2016 menunjukkan bahwa walaupun masih bernilai positif Kabupaten Fakfak selama periode 2011 - 2016 telah mengalami perlambatan ekonomi dari 8,44 persen di tahun 2013 menjadi 5,30 persen pada tahun 2016. Pada tahun 20092011 pertanian menjadi urutan pertama dalam kontribusinya terhadap PDRB Kabupaten Fakfak yang kemudian beralih ke lapangan usaha kontruksi pada tahun 2012. Padahal Kabupaten Fakfak memiliki luas lahan perkebunan pala yang cukup tinggi yaitu 16.010 Ha pada tahun 2016 yang tersebar pada seluruh Distrik di Kabupaten Fakfak (BPS, 2017). Luas kawasan hutan dan perairan Kabupaten Fakfak pada tahun 2016 adalah 948,79 ribu Ha. Kawasan hutan terluas adalah hutan produksi dengan luas 897,46 ribu Ha dan lokasi hutan terluas berada di Distrik Bomboray yaitu 36,70 persen dari total luas hutan produksi di Kabupaten Fakfak. Kabupaten Fakfak juga memiliki aset perairan seluas 2.292 kilometer persegi dengan panjang pantai $484 \mathrm{mil}$ laut. Berdasarkan rekapitulasi jasa sewa aset (cool stroage) Dinas Perikanan dan Kelautan Kabupaten Fakfak tahun 2016 diketahi bahwa total tangkapan ikan adalah sebanyak 2.286 ton. Jumlah ikan yang paling banyak dijual keluar daerah adalah ikan campuran (179.640 Kilogram) dan telur ikan terbang (176.000 Kilogram).

Sensus Kesejahteraan Kabupaten Fakfak (2015) menggambarkan bahwa wilayah perdesaan dengan potensi sumberdaya alam yang melimpah seperti Distrik Kokas dengan potensi perikanan, pariwisata dan perkebunan memiliki tingkat kemiskinan sebesar 40,5 persen, lebih tinggi dibandingkan wilayah perkotaan. Tingkat pengganguran terbuka di Kabupaten Fakfak mengalami peningkatan dari 2,99 persen di tahun 2014 menjadi 9,01 persen ditahun 2015 (BPS, 2016). Hal ini mengindikasikan bahwa Fakfak memiliki surplus tenaga kerja tetapi kesempatan kerja terbatas. Oleh sebab itu ekonomi kreatif di daerah ini sudah seharusnya dikembangkan untuk mengatasi kondisi perekonomian daerah karena merupakan sektor unggulan yang dapat mendukung perekonomian daerah yang berkelanjutan.

Ekonomi kreatif (Howkins dalam Saksono, 2012) merupakan aktivitas perekonomian yang lebih mengandalkan ide atau gagasan (kreatif) untuk mengelola bahan baku yang berasal dari lingkungan sekitarnya menjadi produk yang memiliki nilai tambah ekonomi. Ekonomi kreatif adalah ekonomi yang berlandaskan kreatifvitas dan inovasi yang mengacu pada kearifan lokal sehingga terjadi peningkatan daya saing baik di pasar domestik maupun pasar internasional (Saksono, 2012). Badan Ekonomi Kreatif Nasional, (2016) mendefinisikan ekonomi kreatif sebagai penciptaan nilai tambah berbasis ide yang lahir dari kreativitas sumberdaya manusia (orang kreatif) dan berbasis ilmu pengetahuan, termasuk warisan budaya dan teknologi. Ekonomi kreatif mencakup beberapa sektor yakni arsitektur, desain interior, desain komunikasi visual, fotografi, kriya, kuliner, musik, fesyen, aplikasi dan game developer, penerbitan, periklanan, televisi dan radio, seni pertunjukan dan seni rupa. Data Listing Sensus Ekonomi (2016) menggambarkan bahwa sebaran ekonomi kreatif di pulau Jawa terutama Propinsi Jawa Barat didominasi oleh sektor kuliner $(67,66 \%)$, disusul oleh sektor fesyen $(15,00 \%)$ dan kriya $(14,56 \%)$.

Ekonomi kreatif dalam konteks perekonomian daerah terkait dengan kemampuan pemerintahan daerah untuk menstimulasi pertumbuhan ekonomi, bisnis dan investasi yang berorientasi pada daya saing menuju transformasi industri kreatif dan dapat meningkatkan kesejahteraan masyarakat (Saksono, 2012). Dalam upaya mendorong pertumbuhan ekonomi kreatif diperlukan beberapa pra-kondisi yakni; (1). melakukan identifikasi dan inventarisasi sektor ekonomi kreatif di daerah; (2). membangun database; (3). merumuskam kebijakan, orientasi, target capaian, dan strategi pengembangan; (4). meningkatkan kapasitas kelembagaan pengelola ekonomi kreatif di daerah; (5). menata prosedur, mekanisme, dan jaringan untuk pemasaran produk baik di pasar domestik maupun internasional; (6). meningkatkan kompetensi sumberdaya manusia (SDM); (7). menjamin 
kualitas produk dan pelayanan pasca jual; dan (8). menjamin kelestarian lingkungan untuk menjaga keberlanjutan usaha. Indikator pemeringkatan ekonomi kreatif mencakup beberapa elemen yaitu sektor ekonomi kreatif, aktor yang bekerja secara langsung, tahapan proses dan kapasitas ungkit, (Badan Ekonomi Kreatif Nasional, 2016).

Penelitian ini dilakukan untuk memetakan potensi pengembangan ekonomi kreatif daerah sebagai pra-syarat pengembangan ekonomi kreatif di Kabupaten Fakfak. Pemeringkatan EKRAF dilakukan dengan memberikan pembobotan pada setiap elemen di dalam indicator dari dimensi-dimensi EKRAF di Kabupaten Fakfak. Hasil pembobotan terhadap 14 sektor EKRAF di Kabupaten Fakfak kemudian akan mengidentifikasi sektor-sektor potensial berdasarkan nilai tertingi yang dimiliki oleh setiap sektor EKRAF.

\section{METODE PENELITIAN}

Penelitian ini tidak menguji hipotesis atau tidak Penelitian ini dilaksanakan selama bulan Oktober 2018 di beberapa lokasi (Distrik Arguni, Distrik Kokas, Distrik Kramomongga dan Kota Fakfak) yang merepresentasikan wilayah-wilayah urban, semi-urban dan pinggiran (remote) dengan potensi sumberdaya alam dan sumberdaya manusia yang potensial untuk pengembangan ekonomi kreatif. Pengumpulan data dilakukan dengan beberapa teknik yaitu wawancara, pengamatan (observasi), studi pustaka (literatur) dan diskusi kelompok terfokus (FGD). Paritispan dalam penelitian ini meliputi akademisi, pelaku usaha, kreator, komunitas, pemerintah daerah, tokoh adat, dan beberapa informan kunci terkait dengan pengembangan ekonomi kreatif yang jumlahnya ditentukan sesuai kejenuhan data. Wawancara didasarkan pada daftar pertanyaan atau isu yang telah disiapkan terlebih dahulu selain survey dengan kuisioner tertutup. Datadata yang dikumpulkan kemudian dianalisis dengan menggunakan menggunakan alat Analisis Hirarki Proses (AHP) yang dibantu dengan program aplikasi expert choice. Aspek yang dinilai adalah dari empat elemen yang telah ditentukan oleh Deputi Infrastruktur Badan Ekonomi Kreatif Indonesia, yakni sektor ekonomi kreatif, aktor, tahapan proses dan daya ungkit. Daya ungkit tidak dibahas dalam penelitian ini karena penelitian ini lebih terfokus pada indentifikasi sektor-sektor potensial yang akan dikembangkan menjadi sektor ekonomi kreatif.

Metode Analisis Hirarki Proses (AHP) adalah metode yang dapat digunakan oleh pengambilan keputusan agar dapat memahami kondisi suatu sistem dan membantu dalam melalukan prediksi berdasarkan penilaian, pertimbangan yang logis dan sistematis (Saaty dan Niemira, 2006). Aplikasi AHP dapat dikelompokkan ke dalam dua kategori utama yaitu (1) choice (pilihan), yang merupakan evaluasi atau penetapan prioritas dari berbagai alternatif tindakan yang ada, dan (2) forecasting (peramalan), yaitu evaluasi terhadap berbagai alternatif hasil di masa yang akan datang (Ozdemir dan Saaty, 2006).

Penggunaan AHP dimaksudkan untuk proses penelusuran permasalahan untuk membantu pengambilan keputusan memilih strategi terbaik dengan cara: 1) mengamati dan meneliti ulang tujuan dan alternatif strategi atau cara bertindak untuk mencapai tujuan, dalam hal ini kebijakan yang baik, 2) membandingkan secara kuantitatif dari segi biaya/ekonomis, manfaat dan resiko dari tiap alternatif, 3) memilih alternatif terbaik untuk diimplementasikan, dan 4) membuat strategi secara optimal, dengan cara menentukan prioritas kegiatan (Saaty, 1993).

Beberapa keuntungan dari penggunaan metode AHP antara lain dapat mempresentasikan suatu sistem yang dapat menjelaskan bagaimana perubahan pada level yang lebih tinggi mempunyai pengaruh terhadap unsur-unsur pada level yang lebih rendah, membantu memudahkan analisis guna memecahkan persoalan yang kompleks dan tidak terstruktur dengan memberikan skala. Selain itu kelebihan AHP dibanding metode lain yaitu struktur yang berhirarki, sebagai konsekuensi dari kriteria yang dipilih sampai pada sub-sub kriteria yang paling dalam, memperhitungkan validitas sampai dengan batas toleransi inkonsistensi berbagai kriteria dan alternatif yang dipilih oleh para pengambil keputusan, memperhitungkan daya tahan output analisis sensitivitas pengambilan keputusan, merupakan suatu model pengambilan keputusan yang komprehensif (Setiyanto dan Irawan 2012).

Langkah-langkah dalam AHP menurut (Saaty, 1993) adalah menentukan tujuan, kriteria, subkriteria, dan alternatif yang kemudian disusun dalam sebuah hirarki. Dalam penelitian ini, tujuan dari AHP adalah untuk menentukan pemeringkatan atau prioritas ekonomi kreatif yang dapat dikembangkan di Kabupaten Fakfak. Aspek yang dinilai adalah empat elemen yang 
telah ditentukan oleh Deputi Infrastruktur Badan Ekonomi Kreatif Indonesia, yakni sektor ekonomi kreatif, aktor, tahapan proses dan daya ungkit. Daya ungkit tidak dibahas dalam penelitian ini karena penelitian ini lebih terfokus pada indetifikasi sektor-sektor potensial yang akan dikembangkan menjadi sektor ekonomi kreatif. Masing-masing elemen memiliki dimensi penilaian untuk merinci masing-masing elemen yang digunakan. Sub-kriteria (dimensi) sektor EKRAF meliputi sumberdaya manusia, bahan baku fisik dan non-fisik, industri, pembiayaan, akses dan perluasan pasar, infrastruktur dan teknologi, kelembagaan; aktor meliputi pemerintah, akademisi, komunitas dan pelaku bisnis. Tahapan proses meliputi kreasi, produksi, distribusi, konsumsi, dan konservasi; dan daya ungkit meliputi keterkaitan ke depan dan ke belakang. Konservasi dalam penelitian ini tidak dibahas secara khusus tetapi telah didiskusikan pada sektor-sektor yang sudah tentu memerlukan tindakan konservasi. Misalnya pemeliharaan dan perlindungan terhadap lingkungan pendukung bagi tersedianya bahan baku dan nilia-nilai sosial budaya penting yang perlu dijaga.

\section{HASIL DAN PEMBAHASAN}

Pemeringkatan sektor ekonomi kreatif menggunakan Analisis Hirarki Proses (AHP), yaitu untuk membandingkan tingkat kepentingan dan ketersediaan elemen/kriteria penilaian. Terdapat tiga kriteria penilaian yang digunakan yaitu penilaian sektor, aktor dan proses. Masingmasing kriteria memiliki sub kriteria yang kemudian digunakan untuk mendapatkan sektor EKRAF yang paling baik atau unggul. Sub kriteria tersebut yaitu ketersediaan sumberdaya manusia (SDM), bahan baku, industri, pembiayaan, akses pasar, infrastruktur, kelembagaan digunakan untuk kriteria sektor. Pemerintah, akademisi, komunitas dan pelaku bisnis, digunakan untuk penilaian kriteria Aktor. Sedangkan kreasi, produksi dan distribusi, digunakan untuk penilaian kriteria kreasi. Pada penilitian ini, setiap kriteria memiliki bobot yang sama, yaitu 0,333 . Berdasarkan hasil analisis AHP kuliner memiliki bobot yang paling tinggi dengan bobot 0,174 dibandingkan sektor lainnya. Urutan kedua adalah kriya $(0,113)$, kemudian pariwisata $(0,099)$, fesyen $(0,86)$ dan seni pertunjukkan dengan bobot 0,70 . Secara rinci pemeringkatan sektor EKRAF di Kabupaten Fakfak dapat dilihat pada Gambar 1.

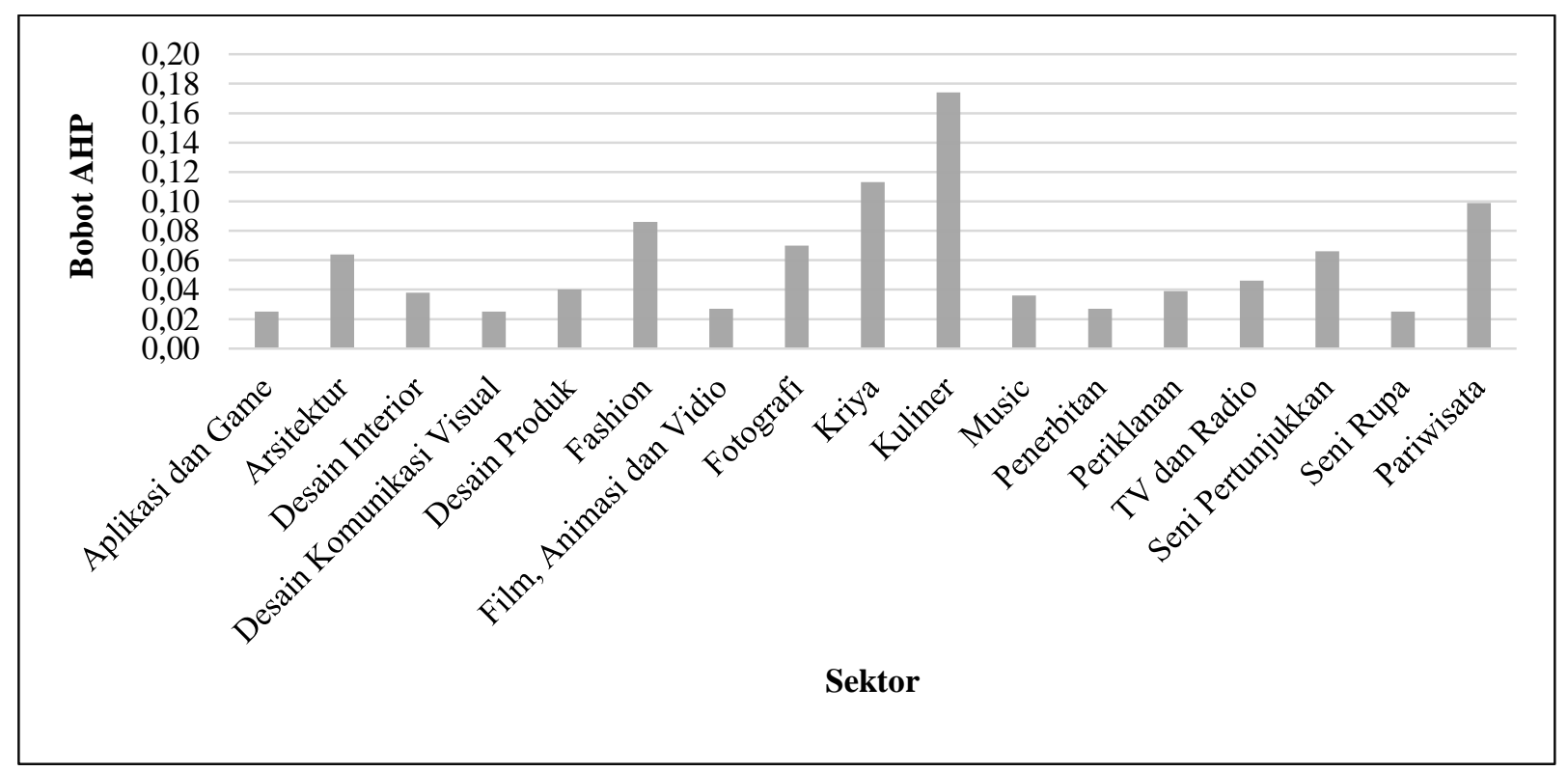

Sumber : Data Primer, 2018

Gambar 1. Hasil AHP Pemeringkatan Sektor Ekonomi Kreatif

Kabupaten Fakfak memiliki potensi kuliner yang sangat besar, apabila ditinjau dari ketersediaan bahan baku yaitu pertanian maupun perikanan. Produk olahan dari pala dan ikan yang diproduksi masyarakat Fakfak cukup banyak. Demikian pula halnya produk olahan durian. Berbeda dengan pala, selama ini olahan durian masih sangat terbatas, dan belum banyak variasinya. Sejauh ini durian masih dijual dalam bentuk produk primer dan hanya pada musim panen durian saja (dua kali setahun). Belum adanya diversifikasi produk 
olahan menyebabkan rendahnya harga durian terutama pada musim panen. Diversifikasi produk durian akan meningkatkan pendapatan petani. Kuliner khas Kabupaten Fakfak lain yang dapat dikembangkan adalah penganan berupa kue lontar dan asida yang biasanya dihidangkan pada acara adat, hari raya atau bulan Ramadhan. Kekhasan kedua penganan ini juga dapat dijadikan peluang usaha bagi masyarakat karena keunikan rasa dan tampilan. Hasil pembobotan pada kriteria penilaian sektor menunjukkan bahwa kuliner memiliki skor paling tinggi diantara sektor lainnya, baik pada dimensi sektor, aktor, dan proses. Secara rinci hasil pembobotan setiap kriteria EKRAF dapat dilihat pada Gambar 2.

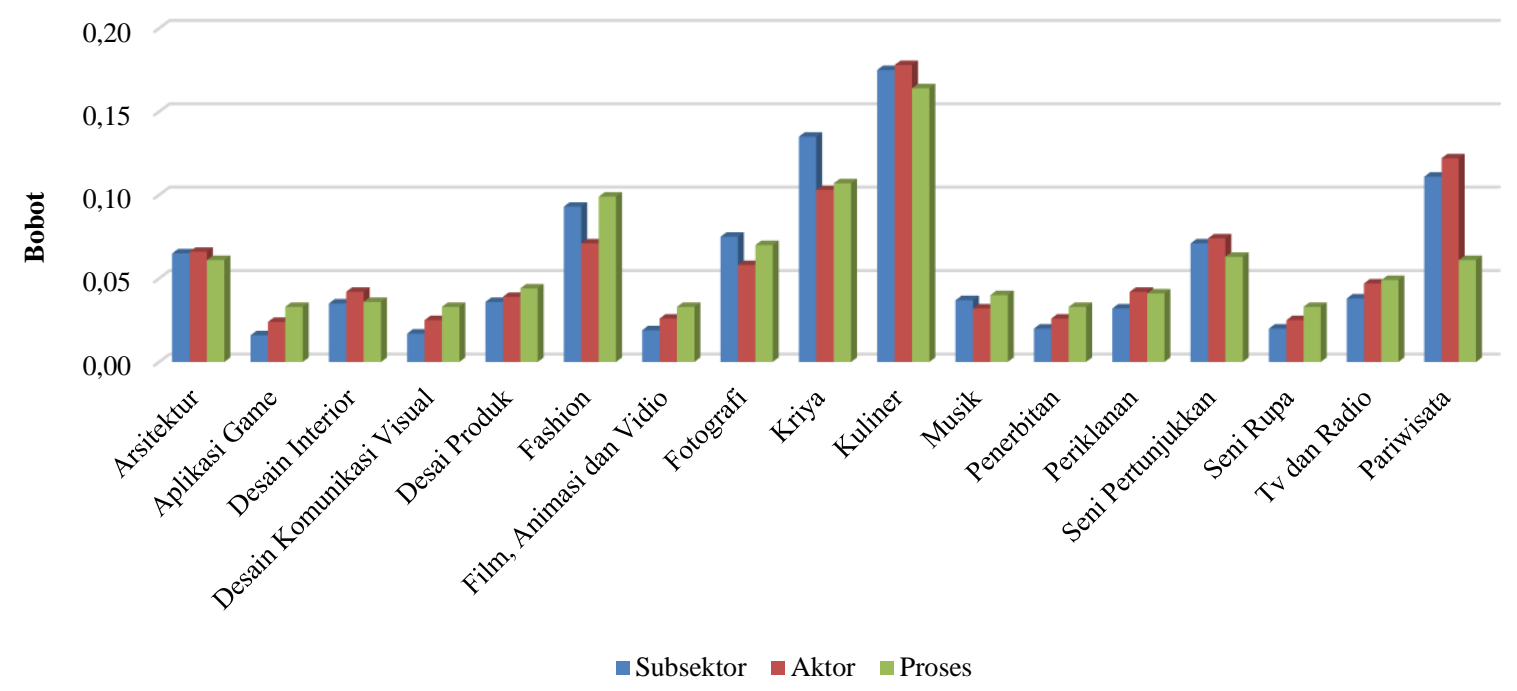

Sumber : Data Primer, 2018

Gambar 2. Hasil Pembobotan Sektor Ekonomi Kreatif

Sektor kuliner memiliki peringkat tertinggi dari sektor lainnya dengan bobot antara 0.164-0,178. Gambar 2 menjelaskan bahwa pada sektor EKRAF kuliner, dimensi sub-sektor, dimensi aktor dan dimensi proses lebih tinggi dibandingkan sektor EKRAF lainnya.

\section{Pembobotan Sub-Elemen Sektor Kuliner}

Penilaian atau pembobotan dimensi sektor didasarkan pada sub-elemen pendukung sektor kuliner yakni ketersediaan sumberdaya manusia, bahan baku, industri, pembiayaan, akses pasar, teknologi dan infrastruktur, dan kelembagaan.

\section{Sumberdaya Manusia}

Pembobotan sub-elemen sumberdaya manusia pada sektor-sektor ekonomi kreatif menunjukkan bahwa kuliner merupakan sektor dengan bobot sumberdaya manusia paling tinggi $(0,165)$ dibandingkan sektor-sektor lainnya. Berdasarkan data BPS Tahun 2017, pengusaha dibidang kuliner sebesar 9.945 orang dalam kegiatan usaha primer (penghasil bahan baku) dan 4.385 orang yang masuk dalam kegiatan usaha pengolahan seperti warung makan, restoran, dan pedagang eceran di Kabupaten Fakfak. Sebagian besar tenaga kerja penghasil bahan baku adalah petani pala dan durian. Jumlah petani pala di Kabupaten Fakfak mencapai 2.300 KK (ILO-PCDP2 UNDP, 2013) atau dengan kata lain tanaman pala bisa menghidupi 9.200 orang anggota rumahtangga tani secara langsung. Sebagian besar petani di Kabupaten Fakfak merupakan masyarakat asli Papua. Jumlah rumahtangga yang bekerja pada perikanan tangkap sebesar 1.769 KK. Selain jumlah tenaga kerja, dalam upaya peningkatan kualitas sumberdaya manusia di bidang usaha makanan olahan, pemerintah telah melakukan banyak kegiatan pelatihan seperti pengolahan pala menjadi berbagai macam olahan, pelatihan pengolahan durian, keladi, ikan dan lain sebagainya.

\section{Bahan Baku}

Bahan baku yang dimaksud disini adalah bahan baku yang digunakan dalam setiap tahapan kegiatan usaha kreatif mulai dari kreasi, produksi, distribusi dan konsumsi. Berdasarkan hasil pembobotan pada 16 sektor EKRAF di 
Kabupaten Fakfak, sektor kuliner memiliki pembobotan tertinggi $(0,160)$.

Ketersediaan bahan baku pada sektor kuliner memiliki bobot yang tinggi. Secara umum Kabupaten Fakfak memiliki total luas area tanaman perkebunan rakyat seluas $12.103,83 \mathrm{Ha}$. Luas areal perkebunan pala rakyat adalah sebesar $17.542 \mathrm{Ha}$ dengan rata-rata produksi 1.750 ton (BPS, Kabupaten Fakfak, 2017). Kabupaten Fakfak juga memiliki potensi durian tetapi belum tersedia data produksi secara berkala. Produksi perikanan tangkap Kabupaten Fakfak adalah 46.196 ton per tahun. Pemasaran ikan dalam bentuk primer (segara) dan telah ada pengolahan berupa abon ikan, ikan asin, dan bakso ikan.

\section{Industri}

Industri adalah salah satu sub-elemen dalam ekonomi kreatif. Berdasarkan hasil pembobotan sub-elemen industri pada sektor kuliner merupakan sub-elemen tertinggi yakni 0, 200. Hal ini dikarenakan jumlah Industri pengolahan pangan di Kabupaten Fakfak sangat banyak dibanding jumlah industri lainnya yaitu sebanyak 131 unit usaha yang tersebar dalam kelompokkelompok usaha seperti warung makan, industri roti dan kue, olahan pala dan durian, krupuk dan kripik serta industri tahu tempe. Dari keseluruhan unit usaha, sektor kuliner mampu mempekerjakan tenaga kerja sebanyak 360 orang.

\section{Pembiayaan}

Sub-elemen pembiayaan dari sektor kuliner berada pada urutan tertinggi $(0,211)$ berdasarkan hasil pembobotan diikuti oleh sektor kriya, fesyen, dan periwisata. Jika dilihat dari pembiayaan, nilai investasi pada industri kuliner sebesar Rp 3.184.500.000 per tahunnya dengan nilai produksi sebesar $\mathrm{Rp}$ 16.341.020.000 dan nilai bahan baku Rp 4.413.700.000.

\section{Akses Pasar \\ Askses pasar merupakan salah satu sub-elemen yang dikaji dalam penelitian pemetaan ekonomi kreatif daerah. Hasil pembobotan dari sub-elemen akses pasar dari keenam belas sektor EKRAF di Fakfak menunjukkan bahwa sektor kuliner memiliki bobot tertinggi yakni 0, 195 .}

Menurut Muzakar (2016) secara umum permintaan terhadap industri kreatif dipengaruhi oleh dua faktor utama yaitu peningkatan daya beli masyarakat yang mendorong peningkatan permintaan produk yang memiliki elastisitas pendapatan tinggi termasuk produk kreatif dan pertumbuhan jumlah penduduk. Peningkatan jumlah penduduk merupakan potensi bagi pemasaran produk kreatif. Keterbukaan informasi menjadikan produk kreatif menjadi bagian yang tidak terpisahkan dari kehidupan masyarakat dari semua lapisan usia.

Pada sub-elemen akses pasar, kuliner masih tinggi dengan bobot 0,195, diikuti sektor kriya dan pariwisata. Akses pasar pada sektor kuliner tidak saja masuk pada pasar lokal tapi sudah mulai ke luar daerah walaupun jumlah dan kontiunitasnya masih terbatas. Jenis Olahan produk kuliner seperti olahan pala dan ikan hanya baru dipasarkan pada pasar lokal. Hasil produksi masyarakat hanya mampu untuk memenuhi kebutuhan pasar lokal.

Dalam rangka memperluas akses pasar, baik pemerintah maupun lembaga swasta telah membuat program-program pengembangan akses pasar bagi usaha-usaha ekonomi kreatif. Salah satunya "Rumah Kreatif" yang didirikan atas kerja sama pemerintah, lembaga keuangan dan perusahaan swasta (BP Tangguh). Unit bisnis rumah kreatif ini merupakan tempat penampungan berbagai produk kreatif hasil produksi perempuan Fakfak dari kampung, berupa ikan asin, abon ikan, dan sirup pala.

\section{Teknologi dan Infrastruktur}

Teknologi dan infrastruktur merupakan subelemen dalam ekonomi kreatif. Berdasarkan hasil pembobotan EKRAF Kabupaten Fakfak menunjukkan bahwa pada sub-elemen teknologi dan infrastruktur, sektor kuliner memiliki bobot tertinggi yakni 0,177 .

Menurut Suparta (2009) sumberdaya teknologi untuk aktivitas produksi dapat berupa teknologi tradisi (adat), teknologi sederhana, teknologi input tinggi, dan teknologi canggih khususnya untuk komoditas yang secara ekonomis bernilai tinggi/mahal. Pengolahan beberapa produk kuliner seperti pala dan ikan di beberapa kelompok masyarakat di Kabupaten Fakfak telah menggunakan teknologi yang cukup maju, baik teknologi untuk kegiatan produksi maupun kemasan. Walaupun sebagian besar masih menggunakan teknologi yang sederhana. Misalnya pada pengolahan pala, pengusaha sirup pala telah menggunakan alat parut dan alat peras dalam kegiatan produksinya. Sedangkan pada usaha abon ikan, telah menggunakan teknologi kemasan yang baik dan diberi label.

Infrastruktur berupa jalan raya memudahkan dalam transportasi angkutan umum untuk pengembangan kuliner selain jaringan komunikasi dan internet yang memudahkan komunikasi dan informasi. Akses informasi 
sangat penting bagi pelaku usaha maupun bagi konsumen dan produsen, terutama terkait dengan transfer teknologi, informasi modal, pasar, dan inovasi-inovasi lain diperlukan bagi kemajuan usahanya. Selain itu juga informasi tentang keberhasilan-keberhasilan pengusaha lain pada sektor yang sama.

\section{Kelembagaan}

Sub-elemen kelembagaan pada ekonomi kreatif adalah penting. Berdasarkan hasil pembobotan sekor kuliner di Kabupaten Fakfak memiliki bobot terbesar yakni 0,169. Pengembangan industri kreatif Kabupaten Fakfak mendapat dukungan dari beberapa lembaga. Pada sektor kuliner misalnya penelitian ini menunjukkan bahwa peran lembaga pemerintah sangat besar. Dinas Pemberdayaan Perempuan dan Anak,
Dinas Pertanian, dan Perbankan telah secara reguler memberikan bantuan berupa modal, peralatan dan pelatihan-pelatihan untuk pengembangan kapasitas dan usaha kuliner. Dukungan lembaga swasta seperti perusahaan BP Tangguh yang telah menginisisasi pembentukan koperasi dan membina perempuan di beberapa kampung di Kabupaten Fakfak juga cukup signifikan bagi pengembangan sektor kuliner.

\section{Pembobotan Dimensi Aktor}

Aktor dalam ekonomi kreatif merupakan dimensi penting. Dalam pemetaan potensi EKRAF Kabupaten Fakfak, pembobotan terhadap aktor pada setiap sektor EKRAF termasuk kuliner juga dilakukan. Hasil pembobotan dari sektor-sektor EKRAF di Kabupaten Fakfak dapat dilihat pada Gambar 3.

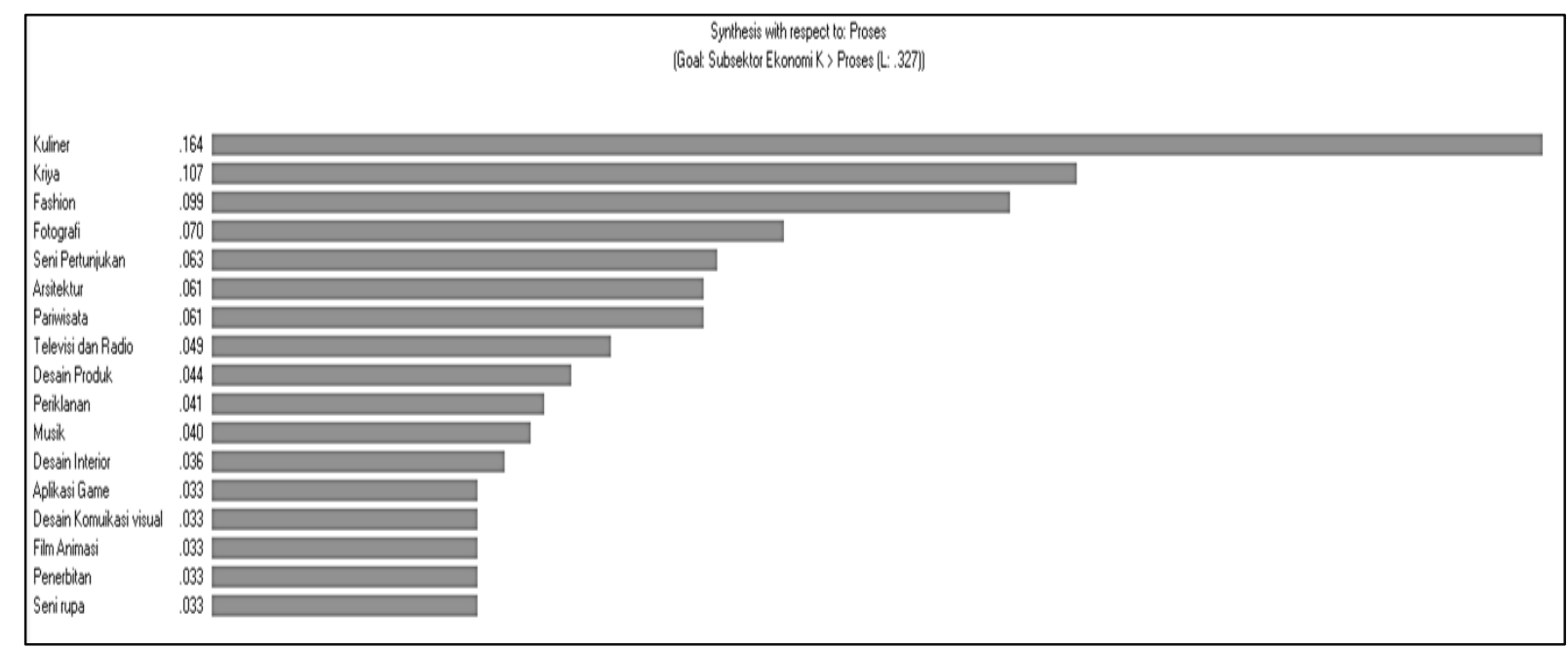

Sumber : Data Primer, 2018

Gambar 3. Hasil AHP Pembobotan Dimensi Aktor

Dimensi aktor yang dinilai adalah pemerintah, pelaku bisnis, komunitas dan akademisi. Dari hasil penilaian AHP, kuliner memiliki bobot tertinggi dibanding sektor lain yakni sebesar 0.178. Penelitian ini menemukan bahwa dukungan pemerintah sebagai penyedia suprastruktur dan infrastruktur yang merujuk pada visi Kabupaten Fakfak, membangun kampung bercahaya sangat mendukung pengembangan sektor kuliner. Suprastruktur yang tersedia pada instansi terkait seperti Dinas Pertanian dan Dinas Pemberdayaan Perempuan, Anak dan Keluarga Berencana dalam programprogran kerjanya mengarah pada pengembangan kuliner yang ada di Kabupaten Fakfak seperti program pelatihan pengolahan pala, durian dan keladi, pelatihan pengemasan, serta program bantuan alat dan modal.
Dalam Dokumen Visi Pembangunan Daerah Kabupaten Fakfak Tahun 2016-2021, Gerbang Kaca merupakan gerakan bersama yang meliputi: 1) gerakan pendataan melalui pembuatan profil kampung, 2) gerakan perencanaan melalui masterplan skenario kampung, 3) gerakan penganggaran melalui proses pengawalan anggaran, 4) gerakan pelaksanaan melalui implementasi program kampung binaan, dan 5) pertanggungjawaban bersama melalui dampak kegiatan lewat pendekatan realistis, komprehensif, dan final. Pada gerakan bersama point 4 , maka setiap dinas mempunyai tanggung jawab untuk membina kampung agar dapat meningkatkan pendapatan masyarakat melalui pemanfaatan potensi dan kekayaan lokal yang ada. Selain penyedia suprastruktur, pemerintah juga bertugas dalam menyediakan infrastruktur yang mendukung pengembangan EKRAF yang 
ada di Kabupaten Fakfak. Infrastruktur yang dibangun bertujuan agak masyarakat mudah dalam proses pemasaran dan penyedia bahan baku. Infrastruktur yang mendukung sektor kuliner antara lain jalan raya, transportasi umum, jaringan telekomunikasi dan penyedia sarana dan prasarana produksi. Selain itu, telah dibuat even festival yaitu Anugrah Pesona Indonesia yang dapat menampilkan dan meningkatkan beberapa sektor EKRAF yang ada di Kabupaten Fakfak. Pemerintah juga telah berupaya untuk meningkatkan apresiasi terhadap Hak Kekayaan Intelektual (HAKI) dari bidang kuliner dan kriya yaitu pendaftaran HAKI untuk Pala, Tomang dan Tifa.

Aktor kedua yang berperan dalam mendukung EKRAF di Kabupaten Fakfak adalah pelaku bisnis. Dari hasil pengamatan ditemukan bahwa jumlah usaha dibidang kuliner paling banyak dibandingkan jumlah usaha yang lain yaitu sekitar $53 \%$ dari total usaha yang ada di Kabupaten Fakfak. Aktor ketiga yang menjadi penilaian adalah peranan akademisi dalam mendukung EKRAF di Kabupaten Fakfak. Terdapat satu perguruan tinggi negeri yang mendukung EKRAF, yaitu politeknik Negeri Fakfak. Program-program yang ditawarkan oleh Politeknik Negeri Fakfak sangat mendukung perkembangan EKRAF di Kabupaten Fakfak yaitu Agroindustri, Teknik Listrik, Teknik Perawatan dan Perbaikan Mesin, Teknik Sipil dan Manajemen Informatika. Selain politeknik juga terdapat sekolah-sekolah menengah kejuruan yang dapat menciptakan sumberdaya manusia yang siap pakai di sektor-sektor EKRAF.

Aktor keempat adalah komunitas. Komunitas yang dimaksud pada penelitian ini adalah sekelompok penduduk yang melakukan usaha pada sektor EKRAF, seperti kelompok koperasi ibu-ibu kampung yang melakukan usaha dibidang kuliner. Komunitas yang telah menghasilkan banyak produksi adalah kelompok ibu-ibu yang memproduksi hasil olahan kuliner seperti pala, ikan dan durian. Bentuk kelompok berupa koperasi atau kelompok bersama simpan pinjam (UBSP). Rata-rata usia kelompok/komunitas pengolah kuliner rata-rata sudah lebih dari 5 tahun. Hal ini membuat kelompok ibu-ibu pengolah kuliner telah memiliki jaringan komunitas yang kuat.

\section{Pembobotan Dimensi Proses}

Pembobotan dimensi proses dilakukan terhadap sektor-sektor EKRAF yang ada di Kabupaten Fakfak pada kriteria-kriteria dimensi proses yakni kreasi, distribusi, dan konsumsi. Secara rinci, hasil pembobotan pada dimensi proses dapat dilihat pada Gambar 4.

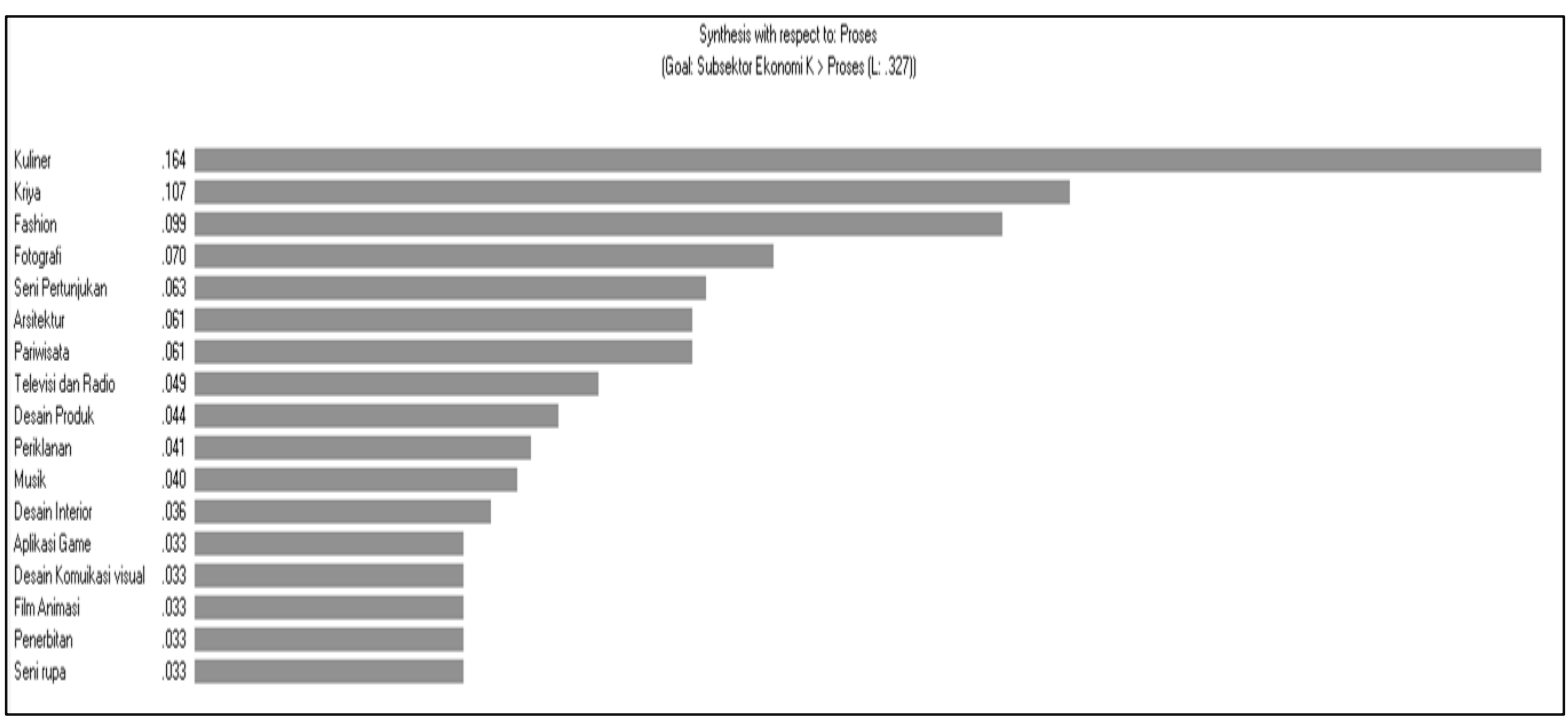

Sumber : Data Primer, 2018

Gambar 4. Hasil AHP Pembobotan Dimensi Proses

Berdasarkan hasil penilaian AHP, sub-sektor kuliner memiliki bobot tertinggi, pada dimensi proses yakni sebesar 0.164. Pada kriteria kreasi, sumberdaya manusia, pengetahuan dan inovasi adalah indicator utama, karena pengetahuan dan inovasi melekat pada sumberdaya manusia

sebagai pelakunya. Ketersediaan sumberdaya manusia untuk sektor kuliner cukup memadai. Hal ini disebabkan karena kuliner termasuk kuliner lokal Fakfak adalah salah satu kebutuhan primer manusia, dengan demikian menjadi usaha yang paling mungkin untuk digeluti. Kuliner lokal yang banyak dijumpai di Kabupaten Fakfak 
antara lain produk turunan pala, turunan durian, turunan ikan, kue lontar, asida dan yang sekarang sedang dikembangkan adalah martabak sagu. Kuliner lokal ini, dari waktu ke waktu mengalami pertambahan varian untuk setiap jenisnya, misalnya asinan pala, terdapat varian basah dan ada kering, pedis dan tidak pedis. Demikian pula halnya dengan kue lontar, terdapat beberapa varian seperti rasa keju, coklat, durian, selain yang original. Hal ini didukung oleh kemampuan pelaku usaha untuk berkreasi dan berinovasi. Walaupun ketersediaan teknologi khusus pada setiap tahapan kreasi di sektor kuliner belum tersedia secara memadai, akan tetapi infrastruktur yang mendukung tahapan kreasi seperti jalan raya, jaringan listrik, internet, frekuensi radio/televisi, dan jaringan telepon sudah cukup memadai.

Ketersediaan ketrampilan khusus pada setiap tahap kreasi, misalnya ketrampilan berijazah/bersertifikat untuk setiap sektor belum tersedia secara memadai, demikian juga halnya dengan ketersediaan lembaga formal maupun informal yang melayani pelatihan, workshop ataupun kursus.

Ketersediaan lembaga perbankan, non-perbankan dan jejaring yang mendukung tahap kreasi di tingkat lokal cukup memadai, hal ini dapat dilihat dengan hadirnya Rumah Kreatif Fakfak, yang merupakan kerjasama antara Bank BNI 46 dan BP Tangguh. Pihak bank memberikan pinjaman modal bagi pelaku usaha. BP Tangguh memberikan pelatihan, menampung dan menjual produk yang dihasilkan melalui Rumah Kreatif Fakfak (RKF). Sejauh ini, produk yang ada di RKF adalah produk kuliner selain produk kriya. Produk yang dijual melalui RKF juga dapat ditemui pada on line shop "Belanja.Com".

Pendekatan dimensi SDM pada proses produksi untuk pekerja di sektor kuliner, sudah tersedia memadai. Ketersediaan bahan baku untuk semua sektor tersedia memadai dengan harga yang terjangkau. Akan tetapi standarisasi/sertifikasi, teknologi dan pengelolaan pada tahapan produksi, dan juga sistem pengendalian mutu bahan baku, konten dan kemasan produk belum memadai. Pemilihan bahan baku masih didasarkan pada pengalaman pelaku usaha, sedangkan peralatan yang digunakan juga masih sederhana. Pada beberapa produk kuliner, pengemasannya sudah baik, terutama untuk produk turunan pala dan produk turunan ikan.

Pendekatan dimensi SDM untuk mendistribusikan produk seperti kurir, belum tersedia memadai, demikian juga untuk pengawas dan manajer, karena umumnya, pelaku usaha juga menjalankan semua fungsi yang ada pada elemen proses. Sejauh ini, sebagian besar pembeli yang mendatangi sentra produksi untuk mendapatkan produk yang diinginkan. Ketersediaan sarana dan prasarana yang memadai, baik angkutan darat, laut dan udara, mempermudah proses distribusi produk. Teknologi kemasan dan labeling untuk mengidentifikasi produk terkait isi atau, konten pada beberapa produk kuliner sudah mulai dilakukan, hal ini dapat dilakukan karena adanya jejaring yang saling mendukung di sektor kuliner.

\section{KESIMPULAN}

Dalam pertumbuhan perekonomian yang melambat ini, pengembangan potensi ekonomi kreatif daerah di Kabupaten Fakfak perlu dilakukan. Pengembangan ekonomi kreatif akan menjaga keberlanjutan ekonomi daerah. Berdasarkan hasil pembobotan potensi ekonomi kreatif daerah, terdapat lima sektor potensial di Kabupaten Fakfak dari 16 sektor EKRAF. Kelima sektor ini memiliki bobot yang tinggi. Hasil Analisis Hirarki Proses (AHP) menyimpulkan bahwa sektor dengan bobot tertinggi adalah kuliner dengan bobot antara $0.164-0,178$. Dimensi-dimensi yang digunakan sebagai indikator dalam penilaian potensi EKRAF adalah dimensi sub-sektor, dimensi aktor dan dimensi proses dengan masing-masing elemen. Pada dimensi sub-sektor sumberdaya manusia dan ketersediaan bahan baku menjadi point tertinggi dalam pengembangan potensi ekonomi kreatif di kabupaten Fakfak. Sedangkan pada dimensi aktor, pemerintah yang memiliki peran yang besar dalam mendukung, membina dan memberikan infrastruktur pada sektor-sektor ekonomi kreatif. Penilian AHP menunjukkan bahwa peran aktor pemerintah memiliki nilai tertinggi pada sektor kuliner.

Walaupun belum ada regulasi secara khusus tentang EKRAF daerah di Kabupaten Fakfak karena EKRAF masih relatif baru, Kabupaten Fakfak telah menginisiasi pengembangan EKRAF daerah dengan melakukan pemetaan potensi EKRAF sebagai pra-syarat pengembangan EKRAF. Beberapa bahan baku terutama sektor kuliner berasal dari sektor pertanian dan atau diambil dari alam tanpa melakukan tindakan budidaya. Oleh sebab itu memperkuat proses produksi dengan memperbaiki beberapa aspek seperti teknologi dan infrastruktur pada proses kreasi sambil menjajaki peluang-peluang seperti perluasan pasar. Kelemahan pada elemen bahan baku adalah 
dipengaruhi oleh musim dan ancaman karena karakteristik produk pertanian. Dimensi proses pada kreasi dan distribusi pada kelima sektor EKRAF ini masih lemah. Sinergitas antara sektor-sektor EKRAF ini masih lemah. Aspek penting lainnya yang berkontribusi terhadap pengembangan EKRAF adalah permodalan. Sebagian besar modal yang digunakan untuk melakukan berbagai bisnis kreatif ini merupakan modal sendiri, bantuan dari lembaga perbankan (beberapa pelaku usaha) dan lembaga nonperbankan.

\section{UCAPAN TERIMAKASIH}

Ucapan terimakasih diberikan kepada masyarakat Fakfak yang terlibat di dalam penelitian ini. Terimakasih juga diberikan kepada BAPPEDA Kabupaten Fakfak yang telah menyediakan dana. Penelitian ini didanai melalui kegiatan swakelola BAPPEDA Kabupaten Fakfak. Selain itu ucapan terimakasih juga diberikan kepada Pemerintah Daerah Fakfak atas fasilitas transportasi yang telah disediakan.

\section{DAFTAR PUSTAKA}

Badan Ekonomi Kreatif Nasional. (2016). Sistem Ekonomi Kreatif Nasional: Panduan Pemeringkatan Kabupaten/Kota Kreatif.

Badan Pusat Statistik. (2016). Profil Ekonomi/Perusahaan 16 sub-sektor Ekraf Berdasarkan Sensus Ekonomi 2016. Badan Pusat Statistik

BPS Kabupaten Fakfak. (2017). Kabupaten Fakfak dalam Angka. Fakfak, Papua Barat: BPS Kabupaten Fakfak

Fajar Kurniawan. (20 Februari 2017). SWOT Analisis: Marketing feasibility study. Youtube. Diunduh dari https://youtu.be/OErZjn2g3Qw

ILO-PCdP2 UNDP. (2013). Laporan Pemetaan Lembaga Keuangan Mikro dan Kajian Situasi Terkini Usaha Mikro di Kabupaten Manokwari dan Fakfak Provinsi Papua Barat. Program Pengembangan Berbasis Masyarakat Fase II.

Khavidhurrohmaningrum. (2013).Strategi dan Perilaku Industri Pengolahan di Kota Semarang Tahun 2017-2011

Mulyana \& Sutapa. (2015). Peran Quadruple Helix dalam meningkatkan kreativitas dan kapabilitas inovasi (Studi pada industry kreatif sektor fashion). In 2nd Conference in Business, Accounting and Management (pp.222-232)
Saaty, Thomas, L. (1993). Pengambilan Keputusan Bagi Para Pemimpin. Proses Hirarki Analitik untuk Pengambil Keputusan dalam Situasi yang Kompleks. Jakarta: Pustaka Binaman Presindo (2016). A Framework for Making Better Decision: How to Make More Effective Site Selection, Store Closing and Other Real Estate Decision. Research Review. 13(1) pp. 1-4

Saksono, H. ( 2012). Ekonomi Kreatif: Talenta Baru Pemicu Daya saing daerah. Pusat Penelitian dan Pengembangan Pemerintahan Umum dan Kependudukan Badan Penelitian dan Pengembangan (BPP) Kementerian Dalam Negeri. Jurnal Bina Praja. Vol 4.No.2 Juni 2012: 93104.

Setyanto, A. \& Irawan, B. (2012). Pengembangan Kawasan Sentra Produksi Pertanian. Bagian Ketiga Metode Penentuan Komoditas Unggulan dan Wilayah Sentra Pengembangan. Pusat Sosial Ekonomi dan Kebijakan Pertanian. Biro Perencanaan Sekretaris Jendral Kementerian Pertanian.

Suparmoko, M. (2002). Ekonomi Publik, untuk Keuangan dan Pengembangan Daerah. Jogjakarta: Andi

Suryana. (2013). Ekonomi Kreatif, Ekonomi Baru: Mengubah Ide dan Menciptakan Peluang. Jakarta: Salemba Empat

Sidauruk, R. (2013). 'Peningkatan Peran Pemerintah Daerah Dalam Rangka Pengembangan Ekonomi Kreatif di Provinsi Jawa Barat'. Jurnal Bina Praja, Vol 5(3), pp. 141-158.

Patel. (2018). https://www.entrepreneur.com/ article/279786 diunduh pada tanggal 2 November 2018. 